Asst. Prof. Dr. Ferat Yilmaz ${ }^{1}$

Original scientific paper

Dicle University, Diyarbakir, Turkey

UDC: 37.034

Res. Ast. Dr. Elcin Ayaz ${ }^{2}$

DOI: $10.5937 /$ IstrPed2101045Y

Dicle University, Diyarbakir, Turkey

\title{
STEM EDUCATION PRACTICES AND MORAL CHARACTER EDUCATION: MCSTEM?
}

\begin{abstract}
The paper deals with the problems of the relationship between the practice of STEM education, which focuses only on scientific disciplines, knowledge, skills and abilities, and opposing views according to which educational practices consisting of scientific or academic disciplines such as STEM and educational practice focus on morality, values and virtues, ie directly considers the possibilities of these differences in attitudes and approaches to education to can be considered together. This paper aims to discuss whether STEM can be considered on the basis of moral character with the support of a compilation piece. In this direction, the discussion in question has been processed and expanded separately from the standpoint of each STEM discipline - science, technology, engineering and mathematics. The paper uses methods of analysis and discourse as a theoretical analysis to investigate the mentioned issue, which examined whether approaches such as STEM-E, STEM-C and STEM-A have a moral point of view. As a result of the literature review, it was concluded that STEM applications can be resolved on a moral basis. Accordingly, suggestions were given to teachers on how to maintain STEM practices within an ethical framework.
\end{abstract}

Keywords: STEM education, design-based engineering practices, moral character education.

\section{INTRODUCTION}

The most popular occupations in the world are centred around such areas as science, technology, engineering and mathematics. Practices of integrated STEM (science, Technology, Engineering and Mathematics) education in which interdisciplinary integration is secured are becoming widespread in educational processes which raise the labour force necessary for business life as a reflection of the claim made above. Besides, including different approaches in the process also contributes to the enrichment of such practices. The letters $E$, $\mathrm{C}$ and $\mathrm{A}$ were added to the abbreviation STEM and thus, the relevant practice of education continued to be integrated into other skills, content, disciplines or approaches such as Entrepreneurship, Computing and Art. It is thought that another approach that can enrich STEM education practices is moral character education. Yet, this paper does not aim to create the popular acronym McSTEM by adding the letters "Mc" by using the initial letters of the

'ferat.yilmaz@dicle.edu.tr, ${ }^{2}$ elcin.ayazz@gmail.com 
phrase "Moral character". Instead, it intends to discuss whether or not STEM can be considered on the basis of moral character with support from works of compilation.

\section{WHAT IS STEM?}

Historically, education was found to be related mostly first to character and then to academic proficiency (Williams, 2000). Such developments as the internet of things, diffusing networks of mobile internet and the use of strong and cheap sensors occurred with phase four of industrialisation (Ozsoylu, 2017), and the changing world standards also configured the goals of education. From now on, individuals are primarily expected to have the life skills required by the digital age (Resnick, 2002). It is expected that individuals should understand the nature of science especially in physical science classes and that they should make scientific inquiries so that they can meet the expectation (Schwartz, Akom, Skjold, Hong, Kagumba, \& Huang, 2007). Therefore, physical science courses are taught on the basis of research and inquiry in many countries, and design-based engineering practices have also been included in the approach in recent years (Kelly,Lesh, \& Baek, 2008). The conception of inquiry-based education was united into the conception of design on the same platform in the models suggested in this context (Wendell, 2008). Such a synthesis manifests itself in the conception of STEM- where the disciplines of science, technology, engineering and mathematics were integrated (National Academy of Engineering [NAE] \& National Research Council [NRC], 2009).

The conception of integrated STEM education can be defined as bringing functionally different disciplines together in an interdisciplinary approach in order to solve problems which cause pressure on humans and on the society (Krajcik \& Delen, 2017). Science- one of the STEM disciplines-enables us to understand the processes of engineering design, the processes lead technological production and technological production gives acceleration to engineering work. While engineering uses the concepts which facilitate thinking in the disciplines of science and mathematics and makes use of technological instruments; mathematics takes on a facilitating role in all of the areas of science, engineering and technology (Honey, Pearson \& Schweingruber, 2014). This situation indicates that STEM disciplines are not integrated accidentally and that they are interrelated in any event. Yet, an integrated STEM approach develops a common conception for those disciplines and it enables to benefit from mutually complementary and enriching aspects. As Kolodner et al (2003) also point out, what is important in the conception of education where STEM disciplines are integrated is the process of engineering design. Students do cyclical practice by going through such stages as designing based on a problem or need relevant to course gains, building, testing and revising in the design process. The working principles of a product in a simple engineering model or of a design suggested are described in the light of scientific principles in this cyclical process. Students are expected to transfer their learning into other situations of design.

\section{SHOULD PRACTICES OF STEM EDUCATION FOCUS ON MORAL CHARACTER?}

There are differing approaches towards the concept of character. One of the approaches considers character in such aspects of virtue as wisdom, courage, humanity, temperance, and transcendence. Accordingly, in each aspect of virtue, the character strengths which are the forms of actualising that aspect of virtue are available. In this context, character strengths such as creativity and curiosity are indicators of wisdom, such strengths as 
honesty and bravery are indicators of courage, such strengths as kindness and love are indicators of humanity, such strengths as fairness and leadership are indicators of justice, such strengths as prudence and self-regulation are indicators of temperance, such strengths as hope and spirituality are indicators of transcendence (Park \& Peterson, 2009). Such an approach involves many cognitive, emotional, interpersonal, civic, protective and sensemaking aspects of character (Peterson \& Park, 2004).

Another approach considers character in two aspects: as performance character and as moral character. Accordingly, performance character contains the characteristics such as industriousness, resolution, creativity and self-discipline-which are necessary for noticing individuals' potential of perfection in an environment of performance. Moral character, on the other hand, contains characteristics such as integrity, justice, sensitivity, respect and cooperation- which are necessary for individuals to achieve success at their interpersonal relations and ethical behaviours (Davidson, Lickona, \& Khmelkov, 2008). Setting out from what is said above, moral character education can be defined as the process of guidance offered individuals in order for them to achieve success at their interpersonal relations and ethical behaviours.

Some people think that focusing on moral character education will harm the academic goals of educational processes-mainly schools (Hoge, 2002). Some others, on the other hand- such as Cofnas (2016) argue that the relationships rationalised between phenomena with which science is concerned and value-loaded virtues with which character education is concerned are doubtful. Accordingly, it can be said that STEM education practices should focus on scientific disciplines, scientific knowledge and on skills and abilities and that discussions focusing on morals or virtue should not be considered in scientific disciplines or in the scope of interdisciplinary approaches such as STEM.

There are also some other views which argue that educational practices consisting of scientific or academic disciplines such as STEM and educational practices focusing on morals, values and virtue can be considered together. According to those views, values should be a part of school climate and they should be connected to academic domains especially (Schaeffer, 1999). Such connections should be made through curricula which contain several opportunities and case studies for virtue teaching such as sciences (Berkowitz, 2002; Lickona, 1997). In this way, students should be helped in creative ways to develop their own character while they develop academically (Williams, Yanchar, \& Jensen, 2003). Even though these recommendations cause doubts that character education practices affect academic achievement in negative ways (Sanchez, 2005), actually it can affect academic achievement in positive ways (Battistich, 2008; Beninga, Berkowitz, Kuehn, \& Smith, 2006; Schwartz, Beatty, \& Dachnowicz, 2006).

Bringing character education and other academic or scientific disciplines or interdisciplinary approaches such as STEM together can help students to develop the moral character (respect, justice, politeness, honesty, etc.) they will need to set up classroom relations which are necessary for creating a positive learning environment (Davidson, Lickona, \& Khmelkov, 2008). More importantly, while character education practices reflect the knowledge and skills required by disciplines such as STEM into the solution of relevant problems, they can also offer students a perspective about why intelligence is important and how it can be used morally (Banks \& Mhunpiew, 2012). Such an approach can inculcate moral values such as righteousness, honesty, integrity, individual responsibility, modesty, 
justice, patience and dependability- which are required by information society (Huitt, 2004) and which STEM education should also consider important. Practices of character education can increase the academic achievement of students who come from different ethnic, cultural, linguistic, social class, ability and gender groups- which are important in STEM projects- and they can also increase students' collaborative work skills which enable their team spirit, sense of commitment and sense of trust to develop (Hill \& Stewart, 1999). All this can be interpreted as that emphasising the development of moral character in practices of STEM education can be very beneficial.

If emphasis can be laid on the development of moral character in STEM education practices, the individuals who are to be raised with STEM education can be made to have certain conception of morals and values in terms of the designs they are going to made- as Zeidler (2016) also stresses strongly. The moral problems that the recommended solutions can cause in the current context of STEM education have to be considered by students (Szostkowski \& Upadhyay, 2019). As a result, the mental knowledge and skills can be supported with moral values and virtue. Not only individuals who think creatively, critically, innovatively or questioningly and who can solve technical problems, but also individuals who have a moral character and who have specialised in STEM disciplines and who have gained the minimum qualifications in this respect can be raised. The likelihood of using science and technology for the benefit of humans and society can be raised by actualising all this.

The fact that STEM education practices should not be an emphasis of character education should be analysed not only with an integrative comparison but also in terms of each discipline constituting STEM. For this purpose, character education was considered as the process of inculcating ethical reflection skills for moral behaviours, and the relations of science, technology, engineering and mathematics- the STEM disciplines- with morals and ethics in the context of character education were analysed one by one.

\subsection{Science and Moral Character}

According to some people, science internally contains ethical principles or moral objectives. Therefore, it does not have such concerns as the benefit or happiness of humans and of society; nor does it offer explanations on how to use technical products within the framework of moral character (Mermutlu, 2015). According to some, however, the values contained by science can have deep moral implications and impacts (Surbone, 2004) because reality can have unbelievably harmful effects on society even when it is distorted with simplifying scientific logic (Adanir, 2005). Therefore, children and adolescents need to participate in science practices as a whole in moral, aesthetic and spiritual aspects and thus to deepen their relations with science and to make their relations a part of their objective (including moral) presence (Witz \& MacGregor, 2003).

Students can develop higher awareness of the social effects of scientific activities as they deepen their relations with science in moral framework, they can become independent individuals and they can recognise and internalise their roles in decision-making. Besides, students can also consider various moral and ethical issues which emerge in the relations of science with the society, they can take on responsibilities in this matter and they can develop a good character in this way (Chowdhury, 2016). Teachers need to make ethical and moral reflections especially in practices such as STEM so that they can help their students in 
this respect; because STEM practices are employed not only for inculcating the gains of science course but also for generating solutions to problems related to STEM areas in real life. As De Vries, Turner, Orfali and Bosk (2007) also state, moral problems and their solutions do not fall from a 'rational-logical' sky; instead, they are created and framed by structures, institutions and practices in which they arise. In that case, STEM practices should be supported with conception of character education so that they do not create moral problems or so that they can create solutions to the existing problems.

Teachers need to act as value mediators in order for students to behave morally and ethically sensitively in such issues as paying attention to assumptions, asking fundamental questions, choosing protocols, designing research, collecting high quality data and formulating and representing the results on the dimension of science to support STEM practices with character education (Mueller \& Zeidler, 2010). Considering the fact that the process of students' deciding on socio-scientific problems is largely shaped by moral thoughts (Sadler \& Zeidler, 2003), it can be said that teachers can benefit from the solving such socioscientific issues as building a nuclear power station and building a dam through STEM practices while acting as value mediators.

\subsection{Technology and Moral Character}

Differing views are available on whether or not there are any ties between technology and morals. Those who hold negative views in this respect do not think that social phenomena which have historically strong ties can change easily through new technologies. They argue that technology cannot be considered independently of individual decisions, legal norms or of government policies and that moral responsibilities and moral liabilities for social changes are not related only to technology. Those who are against the view, however, claim that technology influences social relations in quality and in quantity and therefore there are ties between the concept of morals- which becomes important in society- and technology (Ozlem, 2002). Boenink, Swierstra and Stemerding (2010) contend that technology forces current moral routines in modern societies and cause ethical discussions and that not only hard effects but also the soft effects of technology on moral routines should be brought up for discussion. According to Buyukbingol (2019), technology influences both of the phenomena of morals and crime-which are mutually related. Particularly the fact that technology facilitates crime and hiding a committed crime and that it makes crimes major and moves them away from being traditional indicate that the relationships between technology and morals should be taken seriously. Verbeek (2008) tries to explain the relationships between technology and morals with the concept of "technological mediation". Accordingly, while technologies promote our living quality on the one hand, they can also influence moral decisions and behaviours with possibilities they offer for the actions that can be done. The relationships between technology and morals manifests itself strongly with the concept of technological mediation because ethics searches for answers to the question of "how to behave morally".

The relationships between technology and morals can be analysed in terms of various technologies. The first technologies that come into mind in this context are not technologies such as tractors or handlooms which are regarded as amoral but they are the technologies such as super intelligence (Perdue, 2017), biotechnology, technologies related to genetic engineering, war technologies, wearable technologies and so on- which have moral causes and effects. A considerable number of people agree that practices such as 
cloning related to biotechnology and genetic engineering are unethical and that they should be restricted (Maitin-Shepard \& Rectenwald, 2004). The living and non-living environment have been destroyed by humans through war technologies - in deprivation of ethics (Koch, 2013). The data concerning individuals who use wearable technologies are continuously transferred into other media to process and it can cause ethical problems in terms of intellectual property (Kuzu Demir \& Demir, 2016).

It is important to determine when this aspect of technology-which can cause many ethical or moral problems as mentioned above- should be considered. Albrechtslund (2007) argues that the ethical dimension of technology should be considered at the stage of design in an approach that is sensitive to moral values, that prevents the emergence of moral problems and that is directed to the future rather than after using technology, based on the ethical problems that arise and directed to the past. In a similar approach, Ross (2008) also claims that what social behaviours can be inspired, what behaviours can be hindered, what experiences can be strengthened and what experiences can be weakened by a technology to be developed should be thought in the process of designing the technology, and that the process of thinking can set up natural ties with ethics. According to Feng (2000) also, developing a technology involves a choice. Therefore, socio-moral values should be taken into consideration while at the stage of designing a technology instead of having concerns about the effects of the technology on moral values and issues after the emergence of the technology. For this reason, myths shown in Table 1 should be left aside and the alternative approaches available in the same Table should be chosen for the relationships between technology and moral values or between technology and ethics.

Table 1: The Myts and Alternative Approaches about the Relationships between Technology and Ethics

\begin{tabular}{|c|c|c|c|}
\hline Myths & Interpretations & Effects on ethics & Alternative approaches \\
\hline $\begin{array}{l}\text { Technology } \\
\text { is } \\
\text { autonomous }\end{array}$ & $\begin{array}{l}\text { Technology cannot } \\
\text { be controlled: it } \\
\text { develops according } \\
\text { to its own logic }\end{array}$ & $\begin{array}{l}\text { Discussions on ethics } \\
\text { are trivial }\end{array}$ & $\begin{array}{l}\text { Social context shapes } \\
\text { technology, it can play and it } \\
\text { should play roles in } \\
\text { designing. }\end{array}$ \\
\hline $\begin{array}{l}\text { Technology } \\
\text { is } \\
\text { independent } \\
\text { of values }\end{array}$ & $\begin{array}{l}\text { Technologies are } \\
\text { only instruments / } \\
\text { objects. }\end{array}$ & $\begin{array}{l}\text { Discussions on ethics } \\
\text { are only related to } \\
\text { using technology, } \\
\text { ant not related to } \\
\text { designing it. }\end{array}$ & $\begin{array}{l}\text { Technologies are loaded with } \\
\text { values; values are embedded } \\
\text { in the design of } \\
\text { technologies. Problems } \\
\text { related to values should be } \\
\text { considered earlier }\end{array}$ \\
\hline $\begin{array}{l}\text { Technology } \\
\text { is good in } \\
\text { essence }\end{array}$ & $\begin{array}{l}\text { Technology is } \\
\text { beneficial in its } \\
\text { essence. Technology } \\
\text { should be permitted } \\
\text { to develop without } \\
\text { any external } \\
\text { restrictions. }\end{array}$ & $\begin{array}{l}\text { Discussions on ethics } \\
\text { are unnecessary; } \\
\text { leading the } \\
\text { technology } \\
\text { consciously can even } \\
\text { be harmful. }\end{array}$ & $\begin{array}{l}\text { There are always restrictions } \\
\text { in designing; economic } \\
\text { values tend to be dominant } \\
\text { in the absence of ethical } \\
\text { discussions; setting ethical } \\
\text { goals should be desired. }\end{array}$ \\
\hline
\end{tabular}

Source: Feng, P. (2000). Rethinking technology, revitalizing ethics: Overcoming barriers to ethical design. Science and Engineering Ethics, 6, 207-220.

It can be said that the myths that technology is autonomous, that it is independent of values and that it is good in essence can be maintained not only in the world of technology and manufacturing but also in the world of education by some teachers. Such an argument can prevent students from making ethical reflections into learning activities such as practices of STEM education. Yet, teachers' attaching importance to ethical discussions on the 
technology dimension of STEM education practices, their transfer of the discussions into the stage of designing and their adoption of alternative approaches such as that ethics can play roles in designing, that technologies involve values and that it is necessary to set ethical goals about technologies can make STEM education practices and character education practices meet on a common ground. In this way, students can transfer their ethical discussions that they have in STEM activities which are a part of their educational life into service sectors related to STEM which can become a part of their professional life.

Ethical discussions, in general, can fall behind the technological developments even though it is recommended that the relationships between technology and ethics or morals should be determined while designing the technology- because ethical discussions do not develop in focussed and controlled environments as different from technological developments; competitive markets do not reward ethical perspectives as they reward technological products, and the social dynamics targeted by ethical systems cannot be managed as well as the physical world targeted by technology (Marshall, 1999). Even though this is the situation in markets which come into prominence with their liberal- and therefore competitive and individualistic- properties, educational environments which are careful about the balance between individual interests and social benefits should not become a market. Therefore, it is recommended that teachers should make moral and ethical reflections on the dimension of technology of STEM education practices into the technologies that their students will develop so as to contribute to their' moral character development. Considering Gattiket and Kelley's (1995) finding that children can be more inadequate than adults in immoral situations about using technology, in making their perspectives moral, in feeling that an action is wrong and harmful, in being disturbed by an action and in feeling that an intervention is necessary, it is thought that relating STEM education practices made with small children especially to character education practices is important.

\subsection{Engineering and Moral Character}

Different views are available in engineering, as in technology, in its relationships with ethics and morals. In this respect, Grunwald (2000) contends that the main purpose of engineering is not to develop an ethical system. Even though certain ethical reflections are made in engineering, engineers do not have ethical responsibilities because engineering is actually performed in conformity with ethical standards and because the decisions in engineering are mostly made by higher authorities. According to Kocan (2015), engineering practices do not involve unconditional and ethical or moral values. The value of the practices emerges with individuals' and society's ethical principles, values and meanings. Basart and Serra (2013) argue that engineering should preserve its ties with third generation ethics which requires ethics common to the whole world without rejecting individual ethics- which is the first generation ethics- and social ethics- which is the second generation ethics. Accordingly, engineering ethics should focus on how to integrate sustainable engineering into common life on earth. Significant contributions are expected of engineers to the solution of many problems such as squatting, which emerges as a result of unethical engineering activities, great destruction caused by earthquakes (Coskun, 2007), global warming, rapid urbanisation, increasing inequalities in the distribution of income, failure to prevent poverty and hunger, depletion of natural resources and increasing violence (Talug, Kanber, \& Yalim, 2015). Besides, engineer should also meditate on various ethical issues such as avoiding conflicts of interest, protecting commercial secrets and confidentiality, rights of opposition, occupational liabilities and public safety and liability to protect health and welfare (Lynch \& 
Kline, 2000) because engineers are the moral mediators of a society due to the fact that they have knowledge and skills which are specific to them and which others do not have. Thus, it is extremely important for them to learn to use their power by considering the effects and reflections on the rest of the society. For this reason, the main attitude that engineering students should be inculcated is the real ethical and moral responsibilities in addition to intellectual power (Tougaw \& McCuddy, 2005).

The above-mentioned cases are important not only for engineers who work in STEM service areas or for university students who are going to work in those areas but also for children, adolescents and young people who are introduced to the engineering dimension of STEM in educational institutions prior to university education. Therefore, the knowledge about ethical standards, ethical reasoning skills and powers of ethical willpower of students who have not entered university yet should be increased as in the case of the purpose of engineering ethics at universities while performing STEM-related activities (Harris, Davis, Pritchard, \& Rabins, 1996).

Considering the fact that character education means teaching virtues and that virtue is perfection according to Harris (2008), the relationships between STEM education practices and character education become apparent. Thus, three types of perfection- that is to say, virtue- should be inculcated in all students within the scope of character education as in the case of prospective engineers during university education. The types of perfection are techno-social sensitivity- which means awareness of how technology affects societies, respect for nature and commitment to the common good (public health and public safety).

\subsection{Mathematics and Moral Character}

Associating mathematics with character education as a discipline may be more difficult than other areas. There are several reasons for it. One of them is that mathematics cannot be considered as a discipline which can generate solutions to the concrete problems of humans like science or as a discipline which can put forward products beneficial to humanity like engineering. In other words, mathematics is considered as a series of operations done on paper which is directed to develop the mind and which is only composed of abstract calculations away from the principle of proximity to life. Another reason is that there are not many studies performed in this respect. The third reason is related to the fact that the values mathematics teaching contains is mostly latent- as Bishop, Clarke, Corrigan and Gunstone (2006) also claim. However, it can be analysed with its external value as well as its internal value; and the ties mathematics has with character education can clearly be demonstrated if reflected clearly.

According to Ernest (2018), the internal value of mathematics is a strong discovery about intellectual power, pure thought, reality and about the actual beauty of all this. The externalor social- value of mathematics is its ability to set up interdisciplinary associations with technology and engineering, and thus to contribute to people's living longer, more healthily, more comfortably, more happily, more efficiently and more richly than ever. All this is related to "benefits" as an external value in mathematics. Apart from that, it can also be said that using evidence and justification in mathematics concretises the values of clarity, justice and democracy and thus can create external values (Ernest, 2016). Therefore, mathematics can also be considered as an intellectual discipline of which a series of moral habits can be expected (Dear, 2001). Considering the fact that one of the goals of character 
education is to use intellectual virtues within the framework of moral virtues, the interpretation of the situation can be that mathematics has relationships with character education- just as other academic disciplines.

Considering mathematics as a course as well as a discipline also makes it clear that there are relationships between mathematics and character education. Basically, the mathematics course involves mathematical values such as rationalism and clarity, values related to mathematics education such as controllability and general educational values such as honesty (Bishop, FitzSimons, Seah, \& Clarkson, 1999). All these values can be said to make contributions to students' moral character. Research has shown that books on mathematics (Sahin \& Basgul, 2019; Uzunkol \& Karaca, 2017) can be influential sources that can be used in this respect and that mathematical problems (Asici \& Dede, 2019) and mathematical modelling (Doruk, 2012 ) are the effective instruments usable for this purpose. The research means that mathematics as a discipline and as a course can be a suitable instrument for teaching intellectual and moral values. In this case, it is thought that mathematics can also be associated with character education in the context of moral values in STEM practices.

It is apparent that not only STEM- an interdisciplinary approach- but also each discipline constituting STEM has relationships with character education. In this case, it is necessary to set various objectives and determine competencies by considering the relationships and to analyse whether or not STEM education practices focus on character education.

\section{DO STEM EDUCATION PRACTICES FOCUS ON MORAL CHARACTER EDUCATION?}

The issues considered under the previous headings indicate that STEM education practices need to focus on moral character education. The objectives and competencies of STEM education practices should be analysed to find whether or not there is such focussing in the current situation. Engineering design processes- in which STEM education practices are available- make efforts to inculcate in individuals the gains listed below:

- inculcating in students the skills required by qualified workforce in areas of STEM and thus contributing to manufacturing (Bybee, 2010; Calisici \& Sumen, 2018; DeCoito \& Myszkal, 2018),

- generating solutions to daily life problems and developing the $21^{\text {st }}$ century skills (Roehrig, Moore, Wang, \& Park, 2012; Moore, Stohlmann, Wang, Tank, Glancy, \& Roehrig, 2014),

- $\quad$ raising individuals who can display innovative, creative and critical approaches and who can think in detail and deeply (Crippen \& Archambault, 2012),

- contributing to raising citizens who are courageous and who can cooperate and communicate effectively (Deveci, 2018),

- creating an educational culture to raise individuals who can use technology well, who can programme computers, who can meet the requirements of the job one does, who can make mistakes and who can think sophisticatedly (Akgunduz et al., 2015),

- inculcating everybody the basic competencies in STEM areas even if they do not wish to have a career in STEM areas (Thomasian, 2011),

- increasing students' motivation (Brophy, Klein, Portsmore \& Rogers, 2008),

- inculcating in students research skills in the area of science, designing skills in the area of engineering and the skills of understanding and using symbolic language in the area of mathematics (Atkinson \& Mayo, 2010). 
An examination of the above-mentioned objectives makes it clear that the practices of STEM education do not contain objectives directly about moral character. In this case, it is also necessary to look at the competencies related to STEM education practices. The competencies which individuals working in STEM areas are expected to have (Carnevale, Smith, \& Melton, 2011) and therefore which STEM education practices aim to develop are shown in detail in Figure 1 below:
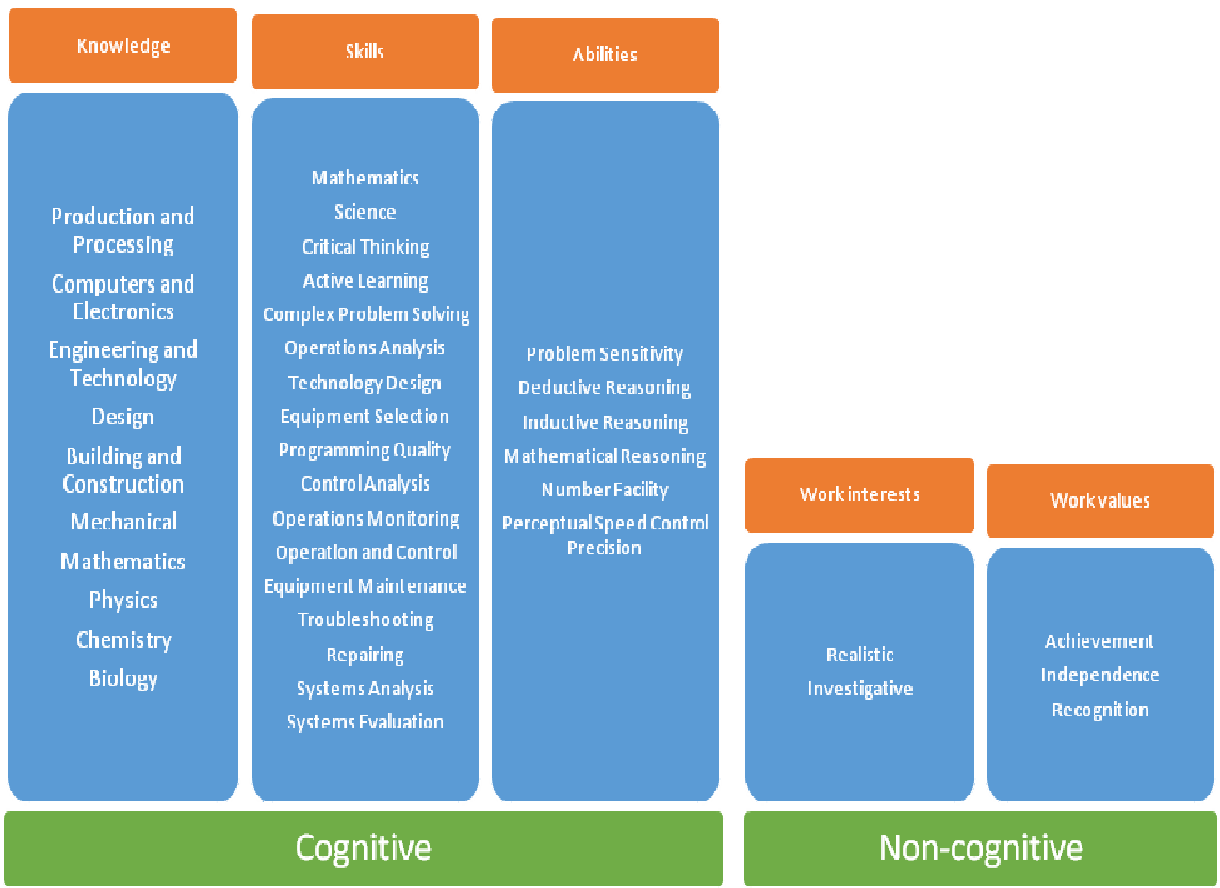

Non-cognitive

\section{STEM-Related Competencies}

Figure 1. STEM-Related Competencies. Carnevale, A. P., Smith, N., \& Melton, M. (2011). STEM: Science Technology Engineering Mathematics. Evaluation Report, Georgetown University Center on Education and the Workforce.

As is clear from Figure 1, individuals who work in STEM areas are mostly expected to have cognitive competencies such as knowledge, skills and abilities. Critical thinking- one of the cognitive competencies- is not considered to be directly associated with moral character although it is a character strength related to the virtue of wisdom. The number/amount of interest and values in the non-cognitive area is small. It is found on examining the values or skills focussed on in this scope that performance character- which is composed of such values as achievement, independence and recognition- rather than moral character is focused on. Yet, a moral value or virtue is not available in STEM education practices in terms of competencies. STEM education practices cannot target the development of moral character directly since individuals who are to work in STEM areas are not expected to have moral competencies. The new and enriched approaches such as STEM-E -which tries to enrich STEM education with entrepreneurship, STEM-C- which tries to enrich STEM 
education with computing and STEM-A- which tries to enrich STEM education with artshould also be analysed to find whether or not they make any contributions in this respect.

The component of entrepreneurship, which STEM-E approach emphasises, can transform STEM education practices with innovation and entrepreneurial leadership (Marshall, 2010). It can raise entrepreneurial individuals suitable to the $21^{\text {st }}$ century workforce (Camesano, Billiar, Gaudette, Hoy, \& Rolle, 2016). Such individuals can have a career in occupations related to STEM disciplines easily (Saiden, 2017). The approach can offer opportunities for practical experience and thus enable students to understand the concepts of STEM and cause them to have interest in them, it can develop skills of working in teams and it can contribute to entrepreneurial thinking (Jin, Li, Ynag, \& Song, 2015). Despite having such advantages, the STEM-E approach may not inculcate moral character clearly, according to a plan and purposefully in students or in other individuals.

The STEM-C approach prioritises computational thinking. Thus, ties are established between computational thinking, STEM education and coding education (Karal, Silbir, \& Yildiz, 2018). This form of thinking is quite important in understanding the new generation standards of science and in raising scientists consistent with the new generation (Weintrop et al., 2016) because computational thinking- which involves such processes as computational reasoning, algorithmic thinking, pattern forming and procedural thinking- enables representing the solutions and thoughts influential in formulating the complex problems related to the real world by putting them to information processing (Wing, 2011). Individuals deal with elements of computational thinking such as abstracting, data collection, data organisation, algorithm, designing, evaluation and visualisation in this process (Swaid, 2015). Yet, students' mind, heart or hands are not concerned with moral values and virtues in this process- as the programme for moral character education aims to do.

The advocates of STEM-A, on the other hand, think that the technically and conceptually deficient parts can be remedied through art-based STEM education (Rabalais, 2014). According to them, engineering and engineering sciences develop individuals logically; but they do not cause any changes culturally. Therefore, supporting STEM education practices by adding the power of art to science and technology is considered important (Jana, 2012); because it is thought that contributions can be made to individuals' affective, cognitive and psychometric development by connecting art and education- which suggest the history of a culture- in the framework of STEM-A approach (Sousa \& Pilecki, 2013). In this context, the products to be produced with STEM in the STEM-A approach are transferred into life with art and aesthetics (Kamen \& Maeda, 2012; Sousa \& Pilecki, 2013). As different from STEM education practices or from other STEM approaches enriched with entrepreneurship and computational thinking, this approach attracts attention in that it is more loaded with values. Yet, it is estimated that those values are not axiologically ethical values and that they cannot fully remedy the lack of moral values or virtues in STEM education practices. As a result, it can be said that STEM practices do not have any components or emphasis related to moral character education which can be described as virtues teaching (Lickona, 1997).

\section{CONCLUSION AND RECOMMENDATIONS}

An image of science which is positive, single methodological, combined, accumulated, antimetaphysical and independent of morals has not been considered adequate since the leap made by philosophers of science such as Karl Popper, Thomas Kuhn, Imre Lakatos, Larry Laudan and Ian Hacking, Ronald Giere and Nancy Cartwright. Instead, the aspect of science 
related to metaphysics and values comes into prominence (Chen, 2010). The rapid advances in science and technology in particular and the chaos increasing in society along with the advances lay emphasis on the importance of morals, values, ethics and their benefits to society (Chowdhury, 2016). Thus, it is necessary to emphasise the importance of all these in STEM education practices- which bring different disciplines related to science and technology together, to place the projects employed in this area into a moral framework or to advance them in a moral line and to conclude them. Otherwise, the probability of raising individuals who can harm the society with their developed mental skills and with their lack in moral character instead of contributing to the society with their intellectual knowledge and skills. And more dangerously, as Mermutlu (2015) states, the probability for some people to use various disciplines such as science- which STEM contains- in legitimising their immoral behaviours emerges; because perceptions of moral character features such as honesty, generosity and kindness rather than the qualities such as being intelligent and creativewhich the practices of STEM education try to develop- make an individual different from psychopathic individuals who can harm society (Glenn, Koleva, lyer, Graham, \& Ditto, 2010). Therefore, STEM education practices should inculcate the features of moral character which will hinder the psychopathic use of those competencies and skills. Thus, it is thought that it could be beneficial for the implementers of STEM education to consider the recommendations below:

- Whether or not a problem disturbs students morally should be questioned at the stage of feeling the problem while determining the problems intended to be solved in daily life. Accordingly, questions such as "Does the problem conflict with your values? Is the problem an obstacle in front of the formation of a moral society? Does the problem activate your moral feelings?" can be asked.

- Questions such as "Can you put forward moral criteria (social benefits, public safety, justice, benevolence, etc.) in recommending the solutions?" can be asked at the stage of generating solutions.

- Questions such as "Was everybody's opinion obtained? Was everybody's opinion considered important? Were different views respected?" can be asked at the stage of deciding on recommendations for solutions.

- A question such as "Does the design cause a moral violation when it is put into action?" can be asked in the prototype drawing of the design which was decided on with the recommendation of the solution.

- The students can be asked the question "Is testing this way of solution ethical?" while testing or revising the recommendations for solutions.

- Questions such as "Can this be regarded as a moral design considering its effects on society, nature and the environment? Does it contain a moral goal? Can it be regarded as a step towards actualising your moral plans about the future? Does a moral motive underly your design?" can be included in the STEM process at the stage of presentation.

- Teachers, in general, should not forget their roles of value mediation in practices of STEM education. They should continuously revise the relationships between each discipline of STEM and morals or ethics.

In conclusion, this study strengthens the thought that STEM education practices can be supported on the basis of moral character- even though it does not create the acronym MCSTEM- and perhaps it prepares the ground to strengthen the acronym MCSTEM. 


\section{REFERENCES}

Adanir, O. (2005). Science, ethics, art. Journal of Art, (7), 83-95.

Akgunduz, D., Aydeniz, M., Cakmakci, G., Cavas, B., Corlu, M. S., Oner, T., \&Ozdemir, S. (2015). STEM education Turkey report (STEM egitimi Turkiye raporu). Istanbul: Scala Basim.

Albrechtslund, A. (2007). Ethics and technology design. Ethics and Information Technology, 9, 63-72. Doi:10.1007/s10676-006-9129-8.

Asici, F., \& Dede, Y. (2019). The Transmission of Educational Values through Mathematical Problems: A Theoretical Study (Matematiksel problemler araciligiyla egitimsel degerlerin aktarimi: Kuramsal bir calisma). Necatibey Faculty of Education Electronic Journal of Science and Mathematics Education, 13(1), 260-283. Doi:http://orcid.org/00000001-7634-4908.

Atkinson, R. D., \& Mayo, M. J. (2010). Refueling the US innovation economy: Fresh approaches to science, technology, engineering and mathematics (STEM) education. The Information Technology \& Innovation Foundation, Forthcoming.

Banks, J., \& Mhunpiew, N. (2012). Authentic leadership, social cognitive theory, and character education: The transforming of theories into practices. US-China Education Review, 12, $1002-1006$.

Basart, J. M., \& Serra, M. (2013). Engineering ethics beyond engineers' ethics. Sci Eng Ethics, 19, 179-187. Doi:10.1007/s11948-011-9293-z.

Battistich, V. A. (2008). Character education, prevention, and positive youth development. Journal of Research in Character Education, 6(2), 81-90.

Beninga, J. S., Berkowitz, M. W., Kuehn, P., \& Smith, K. (2006). Character and Academics: What Good Schools Do. Phi Delta Kappan, 87(6), 448-452. doi.org/10.1177/003172170608700610.

Berkowitz, M. W. (2002). The science of character education. In W. Damon, Bringing in a new era in character education (43-63). Stanford, CA: Hoover Institution Press.

Bishop, A., Clarke, B., Corrigan, D., \& Gunstone, D. (2006). Values in mathematics and science education: Researchers'and teachers' views on the similarities and differences. For the Learning of Mathematics, 26(1), 7-11.

Bishop, A., FitzSimons, G., Seah, W. T., \& Clarkson, P. (1999). Values in mathematics education: Making values teaching explicit in the mathematics classroom. Annual Meeting of the Australian Association for Research in Education and the New Australian Association for Research in Education and the New Zealand Association for Research in Education, (s. 112). Melbourne. Retrieved from: https://eric.ed.gov/?id=ED453075

Boenink, M., Swierstra, T., \& Stemerding, D. (2010). Anticipating the interaction between technology and morality: A scenario study of experimenting with humans in bionanotechnology. Studies in Ethics, Law, and Technology, 4(2), 1-38. Doi:10.2202/19416008.1098

Brophy, S., Klein, S., Portsmore, M., \& Rogers, C. (2008). Advancing engineering education in P-12 classrooms. Journal of Engineering Education, 97(3), 369-387. Doi.org/10.1002/j.2168-9830.2008.tboog85.x.

Buyukbingol, A. (2019). Technology, moral and crime relationship. ISophos: International Journal of Information, Technology and Philosophy, (2), 126-141.

Bybee, R. W. (2010). What is stem education? Science, 329(5995), 996-996. Doi: 10.1126 / science. 1194998

Calisici, H., \& Sumen, O. O. (2018). Metaphorical perceptions of prospective teachers for STEM education. Universal Journal of Educational Research, 6(5), 871-880. DOI: 10.13189/ujer.2018.060509. 
Camesano, T. A., Billiar, K., Gaudette, G., Hoy, F., \& Rolle, M. (2016, January). Entrepreneurial Mindset In STEM Education: Student Success. In VentureWell. Proceedings of Open, the Annual Conference. National Collegiate Inventors \& Innovators Alliance.

Carnevale, A. P., Smith, N., \& Melton, M. (2011). STEM: Science Technology Engineering Mathematics. Georgetown University Center on Education and the Workforce.

Chen, R. (2010). Morality versus science: The two cultures discourse in 1950s Taiwan. East Asian Science, Technology and Society: An International Journal, 4, 99-121. Doi.org/10.1215/s12280-010-9129-y.

Chowdhury, M. (2016). Emphasizing morals, values, ethics, and character education in science education and science teaching. The Malaysian Online Journal of Educational Science, 4(2), 1-16.

Cofnas, N. (2016). Science is not always "self-correcting" fact-value conflation and the study of intelligence. Found Sci(21), 477-492. DOI 10.1007/s10699-015-9421-3.

Coskun, H. (2007). Business ethics of engineering students determination and development of their awareness (Muhendislik Ogrencilerinin is etigi konusundaki farkindaliklarinin belirlenmesi ve gelistirilmesi.) Construction Management Congress. TMMOB-IMO Istanbul Branch.

Crippen, K. J., \& Archambault, L. (2012). Scaffolded inquiry-based instruction with technology: A signature pedagogy for STEM education. Computers in the Schools, 29(1-2), 157-173. Doi.org/10.1080/07380569.2012.658733.

Davidson, M., Lickona, T., \& Khmelkov, V. (2008). Smart \& good schools: A new paradigm for high schools character education. In L. P. Nucci, \& D. Narvaez in, Handbook of moral and character education (370-390). New York, NY: Routledge.

De Vries, R. G., Turner, L., Orfali, K., \& Bosk, C. L. (2007). Social science and bioethics: Morality from the ground up. Clinical Ethics, 2(1), 33-35. doi:10.1258/147775007780267192.

Dear, P. (2001). Mathematics and morality on the cusp of modernity. Revue d'histoire des mathematiques, 7, 277-293.

DeCoito, I., \& Myszkal, P. (2018). Connecting science instruction and teachers' self-efficacy and beliefs in STEM education. Journal of Science Teacher Education, 1-19. doi.org/10.1080/1046560X.2018.1473748.

Deveci, I. (2018). The STEM awareness as oredictor of entrepreneurial characteristics of prospective science teachers (Fen bilimleri Ogretmen adaylarinin sahip olduklari FeTeMM farkindaliklarinin girisimci Ozellikleri yordama durumu). Kastamonu Education Journal, 26(4), 1247-1256. Doi:10.24106/kefdergi.356829.

Doruk, B. K. (2012). Mathematical modeling activities as a useful tool for values education. Educational Sciences: Theory \& Practice, 12(2), 1667-1672.

Ernest, P. (2016). Mathematics and values. In B. Larvor, Mathematical cultures (s. 189-214). Switzerland: Springer.

Ernest, P. (2018). The ethics of mathematics: Is mathematics harmful? In P. Ernest, The Philosophy of Mathematics Education Today (s. 187-216). Switzerland: Springer International.

Feng, P. (2000). Rethinking technology, revitalizing ethics: Overcoming barriers to ethical design. Science and Engineering Ethics, 6, 207-220. Doi.org/10.1007/s11948-000-0049-4.

Gattiket, U. E., \& Kelley, H. (1995). Morality and technology, or Is it wrong to create and let loose a computer virus. 563-573, (s. Proceedings of the 28th Annual Hawaii International Conference on System Sciences).

Glenn, A. L., Koleva, S., Iyer, R., Graham, J., \& Ditto, P. H. (2010). Moral identity in psychopathy. Judgement and Decision Making, 5, 497-505. 
Grunwald, A. (2000). Against over-estimating the role of ethics in technolgy development. Science and Engineering Ethics, 6, 181-196. Doi.org/10.1007/s11948-000-0046-7.

Harris, C. E. (2008). The good engineer: Giving virtue its due in engineering ethics. Sci Eng Ethics, 14, 153-164. Doi:10.1007/s11948-008-9068-3.

Harris, C. E., Davis, M., Pritchard, M. S., \& Rabins, M. J. (1996). Engineering ethics: What? Why? How? And when? Journal of Engineering Education, 85(2), 93-93. Doi.org/10.1002/j.21689830.1996.tboo216.x.

Hill, A., \& Stewart, I. (1999). Character education in business schools: Pedagogical Strategies. Teaching Business Ethics, 3(2). Doi.org/10.1023/A:1009846123335.

Hoge, J. D. (2002). Character Education, Citizenship Education, and the Social Studies. The Social Studies, 93(3), 103-108. Doi.org/10.1080/00377990209599891.

Honey, M., Pearson, G., \& Schweingruber, H. (2014). STEM integration in K-12 education: : Status, prospects, and an agenda for research. Committee on Integrated STEM Education . National Academy of Engineering; National Research Council.

Huitt, W. (2004). Moral and character development. 2014 Educational Psychology Interactive: Retrieved August 5, 2014, from http://www.edpsycinteractive.org/topics/morchr/morchr.html.

Jana, R. (2012). To innovate, scientists and engineers find inspiration in the arts. Smart Planet. Retrieved from: http://www.zdnet.com/article/to-innovate-scientists-and-engineersfind-inspirationin-the-art.

Jin, K., Li, H., Yang, L., \& Song, Q. (2015). Introducing entrepreneurship thinking into STEM curriculum through hands-on projects. International Conferences New Perspectives in Science Education, Edition 3, Florence, Italy.

Kamen. J., Maeda J. (2012). STEM to STEAM: Art Is Key to building a strong economy. Huffington Post-Education. Retrieved from: http://www.huffingtonpost.com/jonkamen/stem-tosteam-artis-key_b_2123099.html

Karal, H., Silbir, G.M., \& Yildiz, M. (2017). STEM egitiminde bilisimsel dusunme ve kodlamanin rolu (STEM egitiminde bilisimsel dusunme ve kodlamanin rolu).(Ed: Salih Cepni). In STEM education from theory to practice (Kuramdan uygulamaya STEM egitimi). Ankara: Pegem Akademi, 389-411.

Kelly, A. E., Lesh, R. A., \& Baek, J. Y. (2008). Handbook of innovative design research in science, technology, engineering, mathematics (STEM) education. NY: Taylor \& Francis.

Kocan, G. (2015). Ethical values and engineering (Etik degerler ve muhendislik). GiDBDERGi, 4, 33-42.

Koch, E. (2013). Human-being responsibility (ethic conscience) in the era of science and technology. Ataturk University Journal of Social Sciences Institute, 17(2), 1-13.

Kolodner, J. L., Camp, P. J., Crismond, D., Fasse, B., Gray, J., Holbrook, J., \& Ryan, M. (2003). Problem-based learning meets case-based reasoning in the middle-school science classroom: Putting learning by design (tm) into practice. The Journal of the Learning Sciences, 12(4), 495-547. Doi.org/10.1207/S15327809JLS1204_2.

Krajcik, J., \& Delen, I. (2017). How to support learners in developing usable and lasting knowledge of STEM. International Journal of Education in Mathematics, Science and Technology, 5(1), 21-28. DOI:10.18404/ijemst.16863.

Kuzu Demir, E. B., \& Demir, K. (2016). Wearable technologies in the field of education: applications, potential benefits, and ethical issues. Paper presented at 4th International Instructional Technologies \& Teacher Education Symposium (ITTES 2016) (pp. 437-440), Firat University, Elazig, Turkey.

Lickona, T. (1997). The Teacher's Role in Character Education. Journal of Education, 179(2), 6380. Doi.org/10.1177/002205749717900206. 
Lynch, W. T., \& Kline, R. (2000). Engineering practice and engineering ethics. Science, Technology, \& Human Values, 25(2), 195-225. Doi.org/10.1177/01622439000250020.

Maitin-Shepard, J., \& Rectenwald, M. (2004). Science, technology, and morality. Retrived from: http://www.andrew.cmu.edu/course/76-101AA/wrtgresources/contribution.pdf

Marshall, K. P. (1999). Has technology introduced new ethical problems? Journal of Business Ethics, 19, 81-90.

Marshall, S. P. (2010). STEM talent: Moving beyond traditional boundaries. Retrieved from: https://digitalcommons.imsa.edu/cgi/viewcontent.cgi?article=1007\&context=marshall.

Mermutlu, A. (2015). Knowledge and science as an ethical problematic realm and modernity (Modernite ve bir etik sorun alani olarak bilgi ve bilim). Dicle University Journal of Ziya Gokalp Education (24), 512-527.

Moore, T. J., Stohlmann, M. S., Wang, H. H., Tank, K. M., Glancy, A. W., \& Roehrig, G. H. (2014). Implementation and integration of engineering in K-12 STEM education. In Engineering in pre-college settings: Synthesizing research, policy, and practices. Purdue University Press.

Mueller, M. P., \& Zeidler, D. L. (2010). Moral-ethical character and science education: EcoJustice ethics through socioscientific issues (SSI). In K. Tobin, \& C. Milne, Cultural studies and environmentalism (s. 105-128). Dordrecht: Springer.

National Academy of Engineering [NAE] \& National Research Council [NRC] (2009). Engineering in K-12 education understanding the status and improving the prospects. Edt. Katehi, L., Pearson, G. \& Feder, M. Washington, DC: National Academies.

Ozlem, D. (2002). Technology is the instrument for human ends (Teknoloji insani amaclari icin bir aractir). Mugla University, Journal Of Institute Of Social Sciences (8), 1-9.

Ozsoylu, A. F. (2017). Industry 4.0 (Endustri 4.0). Journal of Cukurova University Faculty of Economics and Administrative Sciences, 21(1), 41-64.

Park, N., \& Peterson, C. (2009). Character strengths: Research and practice. Journal of College \& Character, 10(4), 1-10. Doi.org/10.2202/1940-1639.1042.

Perdue, R. T. (2017). Superintelligence and natural resources: Morality and technology in a brave new world. Society \& Natural Resources, 30(8), 1206-1031. doi:http://dx.doi.org/10.1080/08941920.2016.1264652.

Peterson, C., \& Park, N. (2004). Classification and measurement of character strengths: Implications for practice. In P. A. Linley, \& S. Joseph, Positive psychology in practice (s. 433-446). New Jersey: John Wiley \& Sons, Inc.

Rabalais, M. E. (2014). STEAM: A national study of the integration of the arts into STEM instruction and its impact on student achievement. (Doctoral thesis). University of Louisiana at Lafayette.

Resnick, M. (2002). Rethinking learning in the digital age. In G. Kirkman (Ed.) The Global information technology report: Readiness for he networked World (pp. 32-37). Oxford: Oxford University.

Roehrig, G. H., Moore, T. J., Wang, H. H., \& Park, M. S. (2012). Is adding the E enough? Investigating the impact of K-12 engineering standards on the implementation of STEM integration. School Science and Mathematics, 112(1), 31-44. Doi.org/10.1111/j.19498594.2011.00112.x.

Ross, P. (2008). Ethics and aesthetics in intelligent product and system design. Eindhoven: Technische Universiteit Eindhoven. Doi:10.6100/IR639294.

Sadler, T. D., \& Zeidler, D. L. (2003). Weighing in on genetic engineering and morality: Students reveal their ideas, expectations, and reservations. Annual Meeting of theNational Association for Research in Science Teaching. Philadelphia. 
Sahin, O., \& Basgul, M. (2019). Ortaokul matematik ders kitaplarinda sosyal degerler. Dicle Universitesi Ziya GOkalp Egitim Fakultesi Dergisi (34), 90-104. Doi:http://dx.doi.org/10.14582/DUZGEF.1890.

Saiden, T. (2017). Towards An Entrepreneurship And Stem Education Primary School Curriculum In Zimbabwe: A Case Study Of Bumburwi Of Gweru District. Advances in Social Sciences Research Journal, 4(18). Doi.org/10.14738/assrj.418.3723.

Sanchez, T. R. (2005). Facing the challenge of character education. International Journal of Social Education, 9(2), 106-111.

Schaeffer, E. F. (1999). It's time for school to implement character education. National Association of Secondary School Principals NASSP Bulletin, 83(609), 1-8. Doi.org/10.1177/019263659908360901.

Schwartz, M. J., Beatty, A., \& Dachnowicz, E. (2006). Character Education: Frill or Foundation?. Principal Leadership, 7(4), 25-30.

Schwartz, R. S., Akom, G., Skjold, B., Hong, H. H., Kagumba, R., \& Huang, F. (2007, April). A change in perspective: Science education graduate students' reflections on learning about NOS. In international meeting of the National Association for Research in Science Teaching, New Orleans, LA (Vol. 18).

Sousa, D. A., \& Pilecki, T. (2013). From STEM to STEAM: Using brain-compatible strategies to integrate the arts [Kindle Fire version]. Retrieved from: http://amazon.com.

Surbone, A. (2004). Genetic medicine: The balance between science and morality. Annals of Oncology, 15(1), i6o-i64. Doi:10.1093/annonc/mdh660.

Swaid, S. I. (2015). Bringing computational thinking to STEM education. Procedia Manufacturing, 3, 3657-3662. Doi.org/10.1016/j.promfg.2015.07.761.

Szostkowski, A., \& Upadhyay, B. (2019). Looking forward by looking back: equity in science education as socially just and morally healing action. Cultural Studies of Science Education, 14, 335-353. Doi.org/10.1007/s11422-019-09916-z.

Talug, C., Kanber, H., \& Yalim, N. Y. (2015). Engineering ethics education in Turkey (Turkiye'de muhendislik etigi egitimi). Turkey Journal of Bioethics, 2(3), 202-212.

Thomasian, J. (2011). Building a science, technology, engineering, and math education agenda: An update of state actions. NGA Center for Best Practices.

Tougaw, D., \& McCuddy, M. K. (2005). Using childhood experiences as an analogy to teach students about the morality of emerging technology. American Society for Engineering Education (1-10). DeKalb, Illinois: Northern Illinois University.

Uzunkol, E., \& Karaca, D. (2017). An Examination of Primary School Math Textbooks With Regard To The Values They Involve (Ilkokul matematik ders kitaplarinin icerdigi degerler bakimindan incelenmesi). International Journal of Field Education, 5(2), 55-71. Doi.org/10.32570/ijofe.637981.

Verbeek, P. P. (2008). Morality in design: Design ethics and the morality of technological artifacts. P. E. al. in, Philosophy and design (91-103). Dordrecht: Springer.

Weintrop, D., Beheshti, E., Horn, M., Orton, K., Jona, K., Trouille, L., \& Wilensky, U. (2016). Defining computational thinking for mathematics and science classrooms. Journal of Science Education and Technology, 25(1), 127-147. Doi 10.1007/s10956-015-9581-5.

Wendell, K. B. (2008). The theoretical and empirical basis for design-based science instruction for children. Unpublished Qualifying Paper, Tufts University.

Williams, D. D., Yanchar, S. C., \& Jensen, L. C. (2003). Character Education in a Public High School: A Multi-Year Inquiry into Unified Studies. Journal of Moral Education, 32(1), 3-33. Doi.org/10.1080/0305724022000073310. 
Williams, M. M. (2000). Models of character education: Perspectives and developmental issues. Journal of Humanistic Counseling, Education and Development, 39(1), 32-40. Doi.org/10.1002/j.2164-490X.2000.tboo091.x.

Wing, J. (2011). Research Notebook: Computational Thinking- What and Why? The Link. Pittsburgh, PA: Carneige Mellon.

Witz, K., \& MacGregor, N. (2003). Morality, spirituality and science in the elementary classroom. In D. L. Zeidler, The role of moral reasoning on socioscientific issues and discourse in science education (165-182). Dordrecht: Kluwer Academic Publishers.

Zeidler, D. L. (2016). STEM education: A deficit framework for the twenty first century? A sociocultural socioscientific response. Cultural Studies of Science Education, 11(1), 11-26. Doi 10.1007/s11422-014-9578-z.

\section{Biographical notes:}

Ferat Yilmaz has a Ph.D. in primary school teaching from Gazi University. He is an assistant professor in the Ziya Gökalp Faculty of Education at Dicle University. He received his MA in the Institute of Education Sciences at Anadolu University and his BA at Dicle University in Primary School Teaching. His research interests include character education, life sciences teaching in primary schools, and values education.

Elçin Ayaz has a Ph.D. in primary school teaching from Gazi University. She is an research assistant in the Ziya Gökalp Faculty of Education at Dicle University. She received her MA in the Institute of Education Sciences at Firat University and her BA at Firat University in Primary School Teaching. Her research interests include science teaching, STEM education, and environmental education. 